Article

\title{
Investigating the Effect of Experience in an Airport on Pleasure, Satisfaction, and Airport Image: A Case Study on Incheon International Airport
}

\author{
Young Kyung Ryu and Jin-Woo Park * (D) \\ School of Business, Korea Aerospace University, Goyang-si 10540, Korea \\ * Correspondence: jwpark@kau.ac.kr; Tel.: +82-2-300-0354
}

Received: 22 May 2019; Accepted: 20 August 2019; Published: 25 August 2019

\begin{abstract}
This study aimed to empirically explore the effects of the experience economy of Incheon International Airport (IIA) on pleasure, satisfaction, and airport image. A survey was conducted with a total of 416 airport users at IIA, and the collected data were analyzed using a structural equation model. Among the four realms of experience, esthetic experience and escapist experience had positive effects on pleasure. In addition, pleasure had a positive effect on satisfaction and airport image, and that satisfaction had a significant effect on airport image. It is expected that the results of this study can serve as fundamental data to enhancing the satisfaction level of airport users and increasing the sustainable development of IIA.
\end{abstract}

Keywords: experience economy; pleasure; satisfaction; airport image; sustainable development of airport

\section{Introduction}

Traditionally, airports have been mere transportation bases carrying passengers and cargo. Today, however, airports offer high added value as locations where various services and industrial activities are carried out. In addition, they are recognized as an important means of securing a national competitive advantage, evolving into active service providers that create positive experiences for visitors through diverse experience programs and an efficient use of spaces. An airport terminal also serves as a cultural complex offering a variety of experiences to visitors, including cultural experiences, shopping, and art performances, departing from the traditional concept of a place where passengers simply wait for boarding. By providing these unique, high-end customer experiences, airports are able to cultivate strong images and increase customer satisfaction, differentiating themselves from their competitors [1]. Therefore, enhancing the level of experience can be an important factor in maintaining a competitive advantage and differentiating one airport from neighboring competing airports [2].

Experience is a key factor in forming positive memories; therefore, there is a growing emphasis on the importance of experience [3-5]. In line with this, Pine and Gilmore [6] presented the experience economy theory, which emphasizes the importance of experience as the driving force of the market, in which competition is fiercer than ever. Many experience-related studies based on the experience economy theory have been aggressively performed in Korea, but there is a lack of studies regarding the emotional reactions of airport users from the perspective of the experience economy despite the importance of experience in non-optional physical environments. From the perspective of airport experience, airports are able to contribute to the formation of tourism destinations and an airport brand image by applying a sense of place [7]. Additionally, unique customer experiences at airports are an important factor that positively impact each airport's image and financial performance [1]. 
Therefore, this study aimed to fill a gap in the literature by identifying the effects of airport experience elements on the satisfaction of airport users through a case study of Incheon International Airport (IIA), the representative airport of Korea. An empirical analysis was conducted on the effects of such emotional reactions on customer satisfaction levels with the airport and image formation, and the relation between satisfaction levels and airport image. It is believed that this study can expand the experience economy theory of Pine and Gilmore [6], and its results can be used to establish strategies to enhance sustainable development and competitive advantage, as well as create a positive airport image and enhance the satisfaction level of airport users.

\section{Literature Review}

\subsection{Experience Economy Theory}

As market competition intensifies, the focus of corporate competitive advantage has swiftly moved from the financial perspective centered on products and enterprises to the individual experience-oriented perspective. Moreover, with increased competition, the focus on services has grown, placing an emphasis on the importance of experience [8,9]. Experience is based on the interactions related to service and refers to the close relationship between a company and consumers, along with the emotional interactions with unique and memorable services [8,10-12].

In this context, Pine and Gilmore [6] developed their experience economy theory. This is a new approach for surviving in the market environment of commoditization. The authors introduced experience as a higher-level concept of products and services that are derived from the interactions between a company and individual consumers and defined experience as all of the events that consumers encounter while directly participating in the production process. They argued that companies should prioritize the value of experience as part of a strategy to prevent the commoditization of services and products and to raise their competitive advantage [6]. Experience evolves throughout the four stages of commodity-goods-service-experience along the progression of economic value, and it can be perceived as an impressive next-generation product. As it progresses to higher levels, the value of an economic product rises and is endowed with unique characteristics differentiated by competing products.

Experience is largely divided into the two categories of individual factors (passive and active) and environmental factors (absorption and immersion). Moreover, depending on the level of impact of each factor, it can be further classified into four dimensions of experience: educational, entertainment, esthetics, and escapism. Each of the dimensions can be described as follows. An educational experience is absorptive and active, and it requires customers to actively participate in the event. In other words, consumers play a vital role in experiential events. Therefore, the educational experience occurs when people directly participate in activities and improve their knowledge levels, as is the case with the traditional costume experience and the craft class at IIA $[13,14]$. The entertainment experience is the oldest and most common type in which people passively absorb experiences such as observing others' activities or performances, including live shows, parades (e.g., the royal promenade), and music concerts. Therefore, customers tend to passively engage in entertainment experiences and absorb the experiences rather than immerse themselves in them. The esthetic experience occurs through visual or audio elements and does not involve giving or receiving any influence to or from the surrounding environment. That is, customers interpret the physical environment around them, and existing in that environment pleases the customers $[6,13]$. Therefore, service providers should create a consistent, attractive, and fully immersive environment for customers to perceive esthetic experiences as reality [6]. IIA provides such esthetic experiences within its Korean Cultural Street and other exhibition areas. Finally, the escapist experience refers to a participation-immersion experience through which people forget about reality by being immersed into the environment to which they are exposed [13-15]. Thus, escapist experiences are highly immersive compared to educational and entertainment experiences. Customers participating in escapist experiences engage in the possibility of moving toward a worthwhile place where they spend time and garner satisfaction from that time. 
This phenomenon is reflected in the transition of services shown in the progression of economic value to the experience economy [6]. This may include cultural experience pavilions or duty-free shopping.

Most of the previous studies related to the experience economy theory have identified the relationship between four dimensions of experience and emotional responses. A positive emotional response to experience can be explained by pleasure. Previous studies have also shown positive emotional responses through educational, entertainment, esthetic, and escapist experiences [15-18]. Therefore, this study set the following hypotheses based on the literature.

Hypothesis 1 (H1). Entertainment experience has a positive effect on pleasure.

Hypothesis 2 (H2). Educational experience has a positive effect on pleasure.

Hypothesis 3 (H3). Esthetic experience has a positive effect on pleasure.

Hypothesis 4 (H4). Escapist experience has a positive effect on pleasure.

\subsection{Pleasure, Satisfaction, and Airport Image}

Pleasure can be defined as the result of positive interactions as well as a basic emotional experience $[19,20]$. It can be further defined as the feeling of satisfaction and reward arising from participating in or performing certain activities and, in turn, it is an important factor in maintaining those activities [21]. Finally, it is a multidimensional variable that includes excitement, affect, and perception of competence [22]. Pleasure is also considered to be a component of the theory of motivation, which is an emotional element that can indirectly affect the willingness to participate in activities (Gardner et al., 2016, MacCarthy et al., 2008). This emotional element is deemed to be more essential than verbal interpretations, as it helps to understand the impact of consumer behavior. Therefore, pleasure plays an important role in behavior analysis. Bigne et al. [23] and Ha [24], in their studies analyzing the relation between the four dimensions of experience and pleasure and satisfaction, confirmed that pleasure from experience had a significant impact on satisfaction. In addition, it was found that positive emotions toward a corporate brand were remembered as a pleasant experience, and such pleasant experiences affected the formation of a positive image toward that brand [25]. In this study, the following hypotheses were set based on previous related studies.

Hypothesis 5 (H5). Pleasure has a positive effect on satisfaction.

Hypothesis 6 (H6). Pleasure has a positive effect on airport image.

Satisfaction is a core marketing concept that is still studied intensively. It refers to the comprehensive mental status or consumer reactions arising from the gap (or lack thereof) between an individual's expectations and the actual experience [26-28]. It can also be explained as the overall reactions to a series of situations or the prompt reactions to a situation [29]. In other words, if perceived performance is higher than expected, a positive discrepancy is built in which the customers will be satisfied. On the contrary, if the customer expectation is much higher than the perceived performance, a negative discrepancy is formed, resulting in a negative emotional response in the form of disappointment $[23,30]$. Satisfaction, therefore, can be defined as an overall response to a series of situations or experiences, or an immediate response to a certain situation as well as an evaluation experience after the decision making takes place for a certain choice [29,31]. Anderson et al. [32] argued that satisfaction was the overall evaluation of the entire consumption experience for products and services, and therefore was a basic indicator of the past, present, and future achievements of a company. Satisfaction is particularly important because it is one of the factors that influences customer loyalty and corporate profitability, which are regarded as the main objectives of the sustainable development strategy [33-35]. 
Previous studies on image were mainly conducted with a focus on corporate image and brand image [36]. Considering that IIA implements a consistent image branding strategy through various corporate social responsibility (CSR) activities, this study, based on previous studies on corporate and brand image, defined airport image as follows: a multi-dimensional reaction that reflects the thoughts and emotional aspects of airport users and a unique image differentiated from other airports. Moreover, the airport image includes the goals and plans of the airport, which are also important factors in differentiating the airport from competing airports [37]. Abdullah et al. [38] and Johnson et al. [39] studied the relationship between satisfaction and image using the customer satisfaction index and confirmed that satisfaction had a direct impact on image. It was found that the more positive an individual's experience, the higher the satisfaction, which led to the creation of a positive image. Consequently, the following hypothesis was proposed:

Hypothesis 7 (H7). Satisfaction has a positive effect on airport image.

\section{Methodology}

\subsection{Research Model}

Based on the theoretical background examined earlier, an empirical verification of the relationship among the dimensions of experience (entertainment, education, esthetics, escapism) of IIA, the pleasure and satisfaction of airport users, and airport image was conducted. To achieve this aim, the following research model was established (Figure 1).

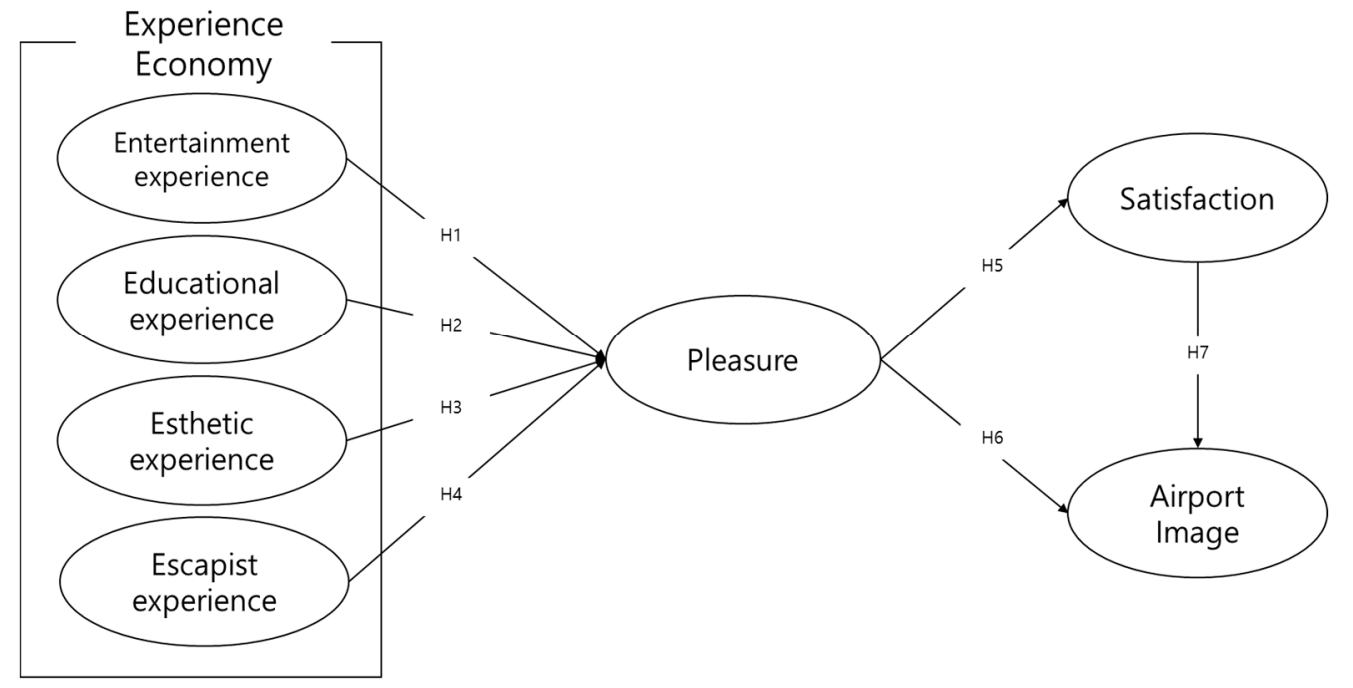

Figure 1. Research Model.

\subsection{Data Collection and Data Analysis}

A survey was conducted in this study with individuals who had visited or used IIA during the prior year. The survey was carried out from 27 April to 13 May 2017 at IIA through a self-administered questionnaire with a total of 416 questionnaires used for the final data analysis. The measurement items on the questionnaire were structured based on previous studies and categorized into the four dimensions (entertainment, education, esthetics, and escapism), and it focused on pleasure, satisfaction, airport image, demographic characteristics, and general characteristics. There were 13 questions regarding airport experience, and four questions assigned each to pleasure, satisfaction, and airport image, respectively. These questions were measured using the Likert 5-point scale (1 point $=$ strongly disagree $\sim 5$ points $=$ strongly agree) $($ Table 1$)$. 
Table 1. Measurement items.

\begin{tabular}{|c|c|c|}
\hline \multicolumn{2}{|c|}{ Measure } & Variables \\
\hline \multirow{4}{*}{ Experience Economy } & Entertainment experience & $\begin{array}{l}\text { The IIA terminal had a special event. } \\
\text { The IIA terminal offered various attractions. } \\
\text { The IIA terminal had an entertainment element. } \\
\text { The IIA terminal had an element that entertained me. }\end{array}$ \\
\hline & Educational experience & $\begin{array}{l}\text { I could experience Korean culture in the IIA Terminal. } \\
\text { The IIA terminal had an element that stimulated my curiosity. } \\
\text { The IIA terminal had an element that elicited my creativity. }\end{array}$ \\
\hline & Esthetic experience & $\begin{array}{l}\text { Overall, I liked the design of the IIA terminal. } \\
\text { The environment of the IIA terminal was attractive. } \\
\text { The IIA terminal fits well with the image of the airport. }\end{array}$ \\
\hline & Escapist experience & $\begin{array}{l}\text { I felt like I was out of my daily life when I spent time at IIA terminal. } \\
\text { The IIA terminal refreshed me. } \\
\text { The IIA terminal offered me a new experience. }\end{array}$ \\
\hline Pleasure & & $\begin{array}{l}\text { I really enjoyed the time I spent at the IIA terminal. } \\
\text { I felt happy while I spent time at the IIA terminal. } \\
\text { I felt interested while I spent time at the IIA Airport terminal. } \\
\text { I felt joy while I spent time at the IIA terminal. }\end{array}$ \\
\hline Satisfaction & & $\begin{array}{l}\text { I am satisfied with the overall experience at the IIA terminal. } \\
\text { IIA was as good as or better than I expected. } \\
\text { I was satisfied with IIA to a greater extent than with other airports. } \\
\text { It was a good experience to visit IIA. }\end{array}$ \\
\hline Airport Image & & $\begin{array}{l}\text { IIA has a distinct image. } \\
\text { IIA has a unique image. } \\
\text { I can clearly imagine the image of IIA. } \\
\text { IIA is different from other airports (e.g., Kimpo Airport). }\end{array}$ \\
\hline
\end{tabular}

In order to analyze the data, SPSS 18.0 and AMOS 21.0 were used. Structural equation modeling (SEM) was conducted to test the hypotheses as SEM provides a better analytical method of empirically examining a theoretical model by including the measurement model and structural model in a single analysis [40]. Confirmatory Factor Analysis (CFA) was also conducted before SEM to verify how well the measured variables represented the individual constructs.

\section{Discussion}

\subsection{Demographic Characteristics}

Table 2 presents the characteristics of the research sample. The gender composition of the sample consisted of 241 females (57.9\%) and 175 males (42.1\%). Regarding age, 179 participants were in their $20 \mathrm{~s}(43.0 \%), 87$ were in their $30 \mathrm{~s}(20.9 \%), 60$ were in their $40 \mathrm{~s}(14.4 \%), 72$ were in their $50 \mathrm{~s}(17.3 \%)$, and 18 were aged 60 or higher $(4.3 \%)$. The responses indicated that 219 participants graduated from (were studying at) a university (24.5\%), 102 graduated from (were studying at) a graduate school $(24.5 \%)$, 74 graduated from (were studying at) a community college (17.8\%), and 21 graduated from (were studying at) a high school or lower-level educational institution (5.4\%). Therefore, more than $80 \%$ of the sample had a college or higher-level degree. The survey results showed that 301 respondents visited the airport 1 to 2 times within the prior year (72.4\%), 83 visited 3 to 5 times (20.0\%), 17 visited 6 to 10 times $(4.1 \%)$, and 15 visited 11 or more times (3.6\%). Regarding the purpose of the airport visit, departures and arrivals comprised the majority with 377 participants $(90.6 \%)$, followed by business (e.g., business meeting) with 24 people (5.8\%), other purposes (e.g., picking up people from the airport) with $11(2.6 \%)$ and transfer with 4 respondents $(1 \%)$. The length of time at the airport was dominated by 2 to $3 \mathrm{~h}$ for 198 of the respondents ( $47.6 \%$ ), followed by 1 to $2 \mathrm{~h}$ for 120 participants (28.8\%), $3 \mathrm{~h}$ or longer for 72 people (17.3\%) and less than $1 \mathrm{~h}$ for 26 respondents $(6.3 \%)$. 
Table 2. Sample Characteristics.

\begin{tabular}{|c|c|c|c|}
\hline \multicolumn{2}{|c|}{ Classification } & \multirow{2}{*}{$\frac{\mathbf{N}}{175}$} & \multirow{2}{*}{$\begin{array}{c}\mathbf{\%} \\
42.1\end{array}$} \\
\hline & Male & & \\
\hline Gender & Female & 241 & 57.9 \\
\hline \multirow{5}{*}{ Age } & 20 to 29 years old & 179 & 43 \\
\hline & 30 to 39 years old & 87 & 20.9 \\
\hline & 40 to 49 years old & 60 & 14.4 \\
\hline & 50 to 59 years old & 72 & 17.3 \\
\hline & 60 years old or older & 18 & 4.3 \\
\hline \multirow{4}{*}{ Number of visits } & $1-2$ times & 301 & 72.4 \\
\hline & $3-5$ times & 83 & 20 \\
\hline & 6-10 times & 17 & 4.1 \\
\hline & 11 times or more & 15 & 3.6 \\
\hline \multirow{4}{*}{ Purpose of visits } & Arrival or departure & 377 & 90.6 \\
\hline & Transfer & 4 & 1 \\
\hline & Business & 24 & 5.8 \\
\hline & Other & 11 & 2.6 \\
\hline \multirow{4}{*}{ Time spent at the airport } & less than $1 \mathrm{~h}$ & 26 & 6.3 \\
\hline & $1-2 \mathrm{~h}$ & 120 & 28.8 \\
\hline & $2-3 \mathrm{~h}$ & 198 & 47.6 \\
\hline & $3 \mathrm{~h}$ or more & 72 & 17.3 \\
\hline \multirow{6}{*}{ Monthly income } & KRW $1,000,000$ or less & 124 & 29.8 \\
\hline & KRW 1,000,000-1,900,000 & 51 & 12.3 \\
\hline & KRW 2,000,000-2,900,000 & 102 & 24.5 \\
\hline & KRW 3,000,000-3,900,000 & 63 & 15.1 \\
\hline & KRW 4,000,000-4,900,000 & 38 & 9.1 \\
\hline & KRW 5,000,000 or more & 38 & 9.1 \\
\hline Total & & 416 & 100 \\
\hline
\end{tabular}

\subsection{Reliability and Validity Test}

This study conducted a CFA to analyze whether the measurement variables and the factor structure of the potential variables based on verified theories from previous studies were appropriate. The absolute fit indices show how well the model indicated by the researchers reproduces the observed data [40]. The Goodness-of-Fit Index (GFI), Adjusted Goodness of Fit Index (AGFI), Normed Fit Index (NFI), Tucker Lewis Index (TLI), Comparative Fit Index (CFI), and Root Mean Square Residual and Root Mean Square Error are used in this study. The GFI, AGFI, NFI, TLI and CFI ranges between 0 and 1 , with higher values suggesting better fit $[40,41]$. The RMR with good fit have values that less than 0.05 , and approach 0 [41] while the RMSEA is possible between 0.03 and 0.08 with $95 \%$ confidence [40]. The goodness-of-fit model analysis results $\left(X^{2}=810.189, \mathrm{df}=253.978, \mathrm{CMIN} / \mathrm{DF}=3.190, \mathrm{RMR}=0.038\right.$, $\mathrm{GFI}=0.861, \mathrm{AGFI}=0.822, \mathrm{RMSEA}=0.073, \mathrm{NFI}=0.893, \mathrm{TLI}=0.910, \mathrm{CFI}=0.924)$ were good overall, but the GFI and AGFI values did not reach the standard value of 0.9. However, as GFI and AGFI can be affected by the inconsistency attributable to the sample characteristics [41], and CFI is free of those characteristics, the goodness-of-fit of the model could be assessed at an acceptable level because CFI was 0.924 . Moreover, the squared multiple correlations (SMC) value (which indicates the explanation power of the measurement item on the latent variable) of each variable was not less than the standard value of 0.4 , and the critical ratio (CR) value exceeded 2 by a large margin in all cases, showing that the potential variables aptly explained the variations of the relevant measurement variables. Therefore, the measurement model proposed in this study was found to be acceptable. The results of CFA are shown in Table 3. 
Table 3. Results of Confirmatory Factor Analysis.

\begin{tabular}{|c|c|c|c|c|c|c|c|c|}
\hline $\begin{array}{c}\text { Configuration } \\
\text { Concept }\end{array}$ & $\begin{array}{l}\text { Measurement } \\
\text { Items }\end{array}$ & $\begin{array}{l}\text { Non-Standardized } \\
\text { Estimate }\end{array}$ & $\begin{array}{l}\text { Standardized } \\
\text { Estimate }\end{array}$ & S.E & C.R. ${ }^{a}$ & SMC & C.R. ${ }^{b}$ & $a^{\mathrm{c}}$ \\
\hline \multirow{4}{*}{ Entertainment } & Entertainment1 & 1.086 & 0.75 & 0.071 & 15.393 & 0.5 & \multirow{4}{*}{0.859} & \multirow{4}{*}{0.848} \\
\hline & Entertainment2 & 1.002 & 0.768 & 0.063 & 15.816 & 0.7 & & \\
\hline & Entertainment 3 & 1.000(Fix) & 0.774 & - & - & 0.762 & & \\
\hline & Entertainment 4 & 1.065 & 0.765 & 0.068 & 15.745 & 0.758 & & \\
\hline \multirow{3}{*}{ Education } & Education1 & 0.971 & 0.808 & 0.049 & 19.616 & 0.719 & \multirow{3}{*}{0.793} & \multirow{3}{*}{0.775} \\
\hline & Education2 & 1.000(Fix) & 0.881 & - & - & 0.605 & & \\
\hline & Education3 & 0.885 & 0.781 & 0.047 & 18.718 & 0.791 & & \\
\hline \multirow{3}{*}{ Esthetics } & Esthetics1 & 0.877 & 0.774 & 0.05 & 17.409 & 0.726 & \multirow{3}{*}{0.903} & \multirow{3}{*}{0.848} \\
\hline & Esthetics2 & 1.000 (Fix) & 0.867 & - & - & 0.683 & & \\
\hline & Esthetics3 & 0.893 & 0.786 & 0.05 & 17.749 & 0.725 & & \\
\hline \multirow{3}{*}{ Escapism } & Escapism1 & 0.998 & 0.707 & 0.072 & 13.796 & 0.652 & \multirow{3}{*}{0.86} & \multirow{3}{*}{0.859} \\
\hline & Escapism2 & 1.000 (Fix) & 0.767 & - & - & 0.499 & & \\
\hline & Escapism3 & 0.925 & 0.72 & 0.066 & 14.069 & 0.728 & & \\
\hline \multirow{4}{*}{ Pleasure } & Pleasure1 & 0.953 & 0.852 & 0.044 & 21.789 & 0.752 & \multirow{4}{*}{0.934} & \multirow{4}{*}{0.906} \\
\hline & Pleasure2 & 1.006 & 0.827 & 0.048 & 20.775 & 0.599 & & \\
\hline & Pleasure3 & 0.968 & 0.808 & 0.048 & 20.015 & 0.519 & & \\
\hline & Pleasure4 & 1.000(Fix) & 0.853 & - & - & 0.588 & & \\
\hline \multirow{4}{*}{ Satisfaction } & Satisfaction1 & 0.933 & 0.848 & 0.049 & 21.799 & 0.61 & \multirow{4}{*}{0.942} & \multirow{4}{*}{0.901} \\
\hline & Satisfaction2 & 0.977 & 0.89 & 0.041 & 23.581 & 0.776 & & \\
\hline & Satisfaction 3 & 0.872 & 0.778 & 0.046 & 18.977 & 0.652 & & \\
\hline & Satisfaction 4 & 1.000(Fix) & 0.852 & - & - & 0.618 & & \\
\hline \multirow{4}{*}{ Airport Image } & Image1 & 1.028 & 0.871 & 0.044 & 23.364 & 0.585 & \multirow{4}{*}{0.913} & \multirow{4}{*}{0.89} \\
\hline & Image2 & 1.000(Fix) & 0.873 & - & - & 0.6 & & \\
\hline & Image3 & 1.002 & 0.837 & 0.046 & 21.848 & 0.59 & & \\
\hline & Image4 & 0.791 & 0.707 & 0.047 & 16.737 & 0.562 & & \\
\hline
\end{tabular}

Note: ${ }^{a}$ Critical Ratio; ${ }^{\mathrm{b}}$ Construct Reliability; ${ }^{\mathrm{c}}$ Cronbach's $\alpha$.

\subsection{Hypotheses Test}

From the analysis results of the structural equation research model, it was observed that the goodness-of-fit indexes of the model were $\mathrm{CMIN}=943.960, \mathrm{RMSEA}=0.079, \mathrm{RMR}=0.062, \mathrm{GFI}=0.842$, $\mathrm{AGFI}=0.803, \mathrm{NFI}=0.876, \mathrm{TLI}=0.893$, and CFI $=0.906$. Most of the indexes were within the range of the goodness-of-fit, with the exception of the NFI and TLI values, which only deviated slightly out of range. Therefore, it was concluded that the measurement model of this study was appropriate.

The path coefficient between potential variables was confirmed through the structural equation model. As can be seen in Table 4, the impact of entertainment experience on pleasure was $\beta=0.105$, $\mathrm{CR}=0.938(p<0.001)$, and the impact of educational experience on pleasure was $\beta=0.102, \mathrm{CR}=0.836$ $(p<0.001)$, indicating no statistically significant impact. Meanwhile, the impact of esthetic experience on pleasure was $\beta=0.201, C R=3.632(p<0.001)$, and the impact of escapist experience on pleasure was $\beta=0.507, C R=10.285(p<0.001)$, verifying that they had a statistically significant impact. This showed that due to the unique characteristics of the airport, airport users were more affected by psychological elements, including the surrounding environment, than by entertainment or educational elements. The impact of pleasure on satisfaction and airport image was $\beta=0.624, C R=14.681(p<0.001)$ and $\beta=0.229, C R=3.526(p<0.001)$, respectively, showing a statistically significant impact. This meant that the more pleasure an airport user derived, the greater their satisfaction and the more positive their image of IIA. This result was similar to that of previous experience economy studies. In addition, the impact of satisfaction on airport image was observed as $\beta=0.71, C R=8.786(p<0.001)$. From this, it can be said that the higher the satisfaction level of airport users, the more positive the airport image was in their minds. 
Table 4. Results of hypothesis testing.

\begin{tabular}{|c|c|c|c|c|c|c|}
\hline & \multicolumn{3}{|c|}{ Hypothesis Path } & \multirow{2}{*}{$\begin{array}{c}\text { Standardized } \\
\text { Estimate }\end{array}$} & \multirow{2}{*}{$\begin{array}{l}\text { C.R. } \\
0.938\end{array}$} & \multirow{2}{*}{$\begin{array}{r}\text { Result } \\
\text { Rejected }\end{array}$} \\
\hline H1 & Entertainment experience & $\rightarrow$ & Pleasure & & & \\
\hline $\mathrm{H} 2$ & Educational experience & $\rightarrow$ & Pleasure & 0.102 & 0.836 & Rejected \\
\hline $\mathrm{H} 3$ & Esthetic experience & $\rightarrow$ & Pleasure & 0.201 & $3.632 * * *$ & Cannot be Rejected \\
\hline $\mathrm{H} 4$ & Escapist experience & $\rightarrow$ & Pleasure & 0.507 & $10.285^{* * *}$ & Cannot be Rejected \\
\hline H5 & Pleasure & $\rightarrow$ & Satisfaction & 0.624 & $14.681^{* * *}$ & Cannot be Rejected \\
\hline H6 & Pleasure & $\rightarrow$ & Airport image & 0.229 & $3.526^{* * *}$ & Cannot be Rejected \\
\hline $\mathrm{H7}$ & Satisfaction & $\rightarrow$ & Airport image & 0.71 & $8.786^{* * *}$ & Cannot be Rejected \\
\hline
\end{tabular}

\section{Conclusions and Implications}

This study aimed to identify the relationship among the four dimensions of experience presented by Pine and Gilmore [6] and the pleasure, satisfaction, and airport image derived by airport users using IIA. The empirical analysis results of the hypotheses of this study can be summarized as follows. First, it was revealed that among the four dimensions of experience, entertainment experience, and educational experience had no impact on pleasure, whereas esthetic experience and escapist experience did. Escapist experience, in particular, had a significant influence on pleasure. This result suggested that airport users place more importance on experiences through which they can refresh themselves than they do on educational and entertainment programs in the airport. Second, it was confirmed that pleasure had a positive influence on satisfaction and airport image. The more pleasure airport users derive, the higher their satisfaction with the airport, and this enhanced level of pleasure instills a firm impression of IIA. As a result, this can help create a unique airport image differentiated from other airports. This supported the studies by Oishi et al. [42] and Wirtz et al. [43], which analyzed the direct impact of pleasure on satisfaction, as well as the study by Isotalo and Watanen [25], which argued that pleasant brand experience had a positive influence on the formation of brand image. Finally, satisfaction was found to have a positive impact on airport image. This was in line with the results of the study by Abdullah et al. [38] and Johnson et al. [39], which used the customer satisfaction index to verify the relationship between satisfaction, company image, and service image.

In identifying the relationships between experience elements and diverse variables, this study offers the following implications for the future activities of airports. First, it examined the importance of experience in a non-optional physical environment, which had not been previously studied, and analyzed the impact of experience on image. Most previous experience economy studies were restricted to optional events, such as festivals, and usually focused on customer satisfaction and its relationship with behavior intention, but no previous studies analyzed the influence between images. Against this backdrop, this study identified the experience characteristics of IIA based on the experience economy theory, and analyzed and verified the relationships among pleasure, satisfaction, and airport image derived by airport users through an empirical approach. Second, this study provided the data required to establish strategies to enhance user satisfaction and raise the sustainable development of IIA. This is important as these factors are closely related to the competitive advantage of the airport. The findings of this study showed that among the experience dimensions of IIA, escapist experience had the most significant impact on pleasure. Therefore, airport practitioners should provide more diverse experience programs containing escapist elements through which airport users can refresh themselves. This will enhance the level of pleasure and satisfaction of airport users. For example, it is necessary to actively develop content for experience activities along with technology such as virtual reality (VR) experience events or a traditional cultural complex. In addition, as the second-most important factor, it is important to enhance the level of esthetics because airport users place value on a pleasant indoor environment and attractive and sophisticated interior design. With the development of the airport's automation system, the immigration process has become faster. However, due to the particularities of air travel, air 
travelers still need to stay at the airport for three to five hours. Therefore, it is necessary to strengthen services in terms of upgrading the quality of the experiences offered to travelers. For this service improvement, airport practitioners should be able to deploy artwork by world-renowned artists, and/or deploy a wide variety of artwork, to provide psychological rest and healing for airport visitors and travelers. Creating an environment using diverse colors, lighting, and artwork and applying a visually and physically satisfying design for airport users will help create unique experiences and have a positive impact on airport image. Finally, expanding experience-oriented activities in which airport users can directly participate and providing services that foster a pleasurable experience are critical to providing a competitive advantage.

This study had the following limitations. This study was restricted to IIA, and it did not compare the experience dimensions of IIA with those of other advanced airports across the globe. Because some advanced airports in other countries offer experience-oriented services, including exhibitions, to establish airport brand strategies and increase user satisfaction levels, it is necessary for IIA to establish a development plan that incorporates comparisons with other airports. To that end, it is important for future studies to draw out the specific characteristics of experience elements and experience programs by comparing and analyzing other advanced airports around the world based on the experience economy theory, and then apply the results to IIA. Moreover, constructs such as memory, interests, and behavioral intentions could be tested in future studies as additional variables. This would allow for a better understanding of the relationships between experiences and those variables, and it also could extend the theory of experience economy, particularly in an airport context.

Author Contributions: Conceptualization, Y.K.R. and J.-W.P.; methodology, Y.K.R. and J.-W.P.; data collection and analysis, Y.K.R.; supervision of the research, J.-W.P.; writing-original draft, Y.K.R.; writing-review \& editing, Y.K.R. and J.-W.P.

Funding: This research received no external funding.

Conflicts of Interest: The authors declare no conflict of interest.

\section{References}

1. Paternoster, J. Excellent airport customer service meets successful branding strategy. J. Air Transp. Manag. 2008, 2, 218-226.

2. Wattanacharoensil, W.; Schuckert, M.; Graham, A. An airport experience framework from a tourism perspective. Transp. Rev. 2016, 36, 318-340. [CrossRef]

3. Schmitt, B. Experiential marketing. J. Mark. Manag. 1999, 15, 53-67. [CrossRef]

4. Song, H.; Choi, Y.; Lee, C. A study of festival visitors' loyalty based on experience economy: The case of Boryeong Mud festival. Korean. J. Tour. Res. 2011, 25, 179-198.

5. Choi, S.W. The Influence of Theme Park Service's Experience on Brand Equity: Focused on Pine \& Gilmore's Experience Economy Theory. Master's Thesis, Hanyang University, Seoul, Korea, February 2014.

6. Pine, B.J.; Gilmore, J.H. Welcome to the experience economy. Harv. Bus. Rev. 1998, 76, 97-105. [PubMed]

7. Wattanacharoensil, W.; Schuckert, M.; Graham, A.; Dean, A. An analysis of the airport experience from an air traveler perspective. J. Hosp. Tour. Manag. 2017, 32, 124-135. [CrossRef]

8. Gentile, C.; Spiller, N.; Noci, G. How to sustain the customer experience: An overview of experience components that co-create value with the customer. Eur. Manag. J. 2007, 25, 395-410. [CrossRef]

9. Cetin, G.; Akova, O.; Kaya, F. Components of experiential value: Case of hospitality industry. In Proceedings of the 10th International Strategic Management Conference 2014, Rome, Italy, 21 June 2014.

10. Mathwick, C.; Malhotra, N.; Rigdon, E. Experiential value: conceptualization, measurement and application in the catalog and Internet shopping environment. J. Retail. 2001, 77, 39-56. [CrossRef]

11. LaSalle, D.; Britton, T. Priceless: Turning Ordinary Products into Extraordinary Experiences; Harvard Business Press: Brington, MA, USA, 2003; ISBN 978-157-851-746-6.

12. Wu, C.H.; Liang, R.D. Effect of experiential value on customer satisfaction with service encounters in luxury-hotel restaurants. Int. J. Hosp. Manag. 2009, 28, 586-593. [CrossRef] 
13. Oh, H.; Fiore, A.M.; Jeong, M. Measuring experience economy concepts: Tourism applications. J. Travel Res. 2007, 46, 119-132. [CrossRef]

14. Hosany, S.; Witham, M. Dimensions of cruisers' experiences, satisfaction, and intention to recommend. J. Travel Res. 2010, 49, 351-364. [CrossRef]

15. Loureiro, S.M.C. The role of the rural tourism experience economy in place attachment and behavioral intentions. Int. J. Hosp. Manag. 2014, 40,1-9. [CrossRef]

16. Kim, J.H. (A) Study on the Relations among Experience Elements, Pleasure, Satisfaction and Behavioral Intention: Based on Users of Five-Star Hotel Package Products in Seoul. Master's Thesis, Kyung Hee University, Seoul, Korea, February 2010.

17. Lee, Y.Y.; Yoo, B.H. The effects of experiential factors on festival, enjoyment, satisfaction and behavioral intention: An application of Korea wine festival. J. Tour. Leis. Res. 2015, 27, 271-290.

18. Kim, J.H. The Effects of Experience Elements about Hologram Concerts, 3D Hologram Technologies on Pleasure and Behavior Intention: Focus on Experience Economy Theory. Master's Thesis, Hanyang University, Seoul, Korea, August 2016.

19. Russell, J.A. Culture and the categorization of emotions. Psychol. Bull. 1991, 110, 426-450. [CrossRef] [PubMed]

20. Dubé, L.; Le Bel, J. The content and structure of laypeople's concept of pleasure. Cogn. Emot. 2003, 17, 263-295. [CrossRef]

21. Ainley, M.; Hidi, S. Interest and enjoyment. In International Handbook of Emotions in Education; Routledge: New York, NY, USA, 2014; pp. 205-227. ISBN 978-041-589-502-6.

22. Timo, J.; Sami, Y.P.; Anthony, W.; Jarmo, L. Perceived physical competence towards physical activity, and motivation and enjoyment in physical education as longitudinal predictors of adolescents' self-reported physical activity. J. Sci. Med. Sports. 2016, 19, 750-754. [CrossRef]

23. Bigné, J.E.; Andreu, L.; Gnoth, J. The theme park experience: An analysis of pleasure, arousal and satisfaction. Tour. Manag. 2005, 26, 833-844. [CrossRef]

24. Ha, D. Effects of Daegu Gyeongbuk's foreign tourist experience on enjoyment, satisfaction, and loyalty: Pine and Gilmore's experience economy perspective. Tour. Stud. 2009, 24, 359-380.

25. Isotalo, A.W.S. The Impact of Brand Experience on Attitudes and Brand Image-A Quantitative Study. Master's Thesis, Mälardalen University, Västerås, Sweden, 2015.

26. Oliver, R.L. Measurement and evaluation of satisfaction process in retail setting. J. Retail. 1981, 57, $25-48$.

27. Tse, D.K.; Wilton, P.C. Models of consumer satisfaction formation: An extension. J. Mark. Res. 1988, 25, 204-212. [CrossRef]

28. Gerpott, T.J.; Rams, W.; Schindler, A. Customer retention, loyalty, and satisfaction in the German mobile cellular telecommunications market. Telecommun. Policy 2001, 25, 249-269. [CrossRef]

29. Chen, J.K.; Batchuluun, A.; Batnasan, J. Services innovation impact to customer satisfaction and customer value enhancement in airport. Technol. Soc. 2015, 43, 219-230. [CrossRef]

30. Hu, H.H.; Kandampully, J.; Juwaheer, T.D. Relationships and impacts of service quality, perceived value, customer satisfaction, and image: An empirical study. Serv. Ind. J. 2009, 29, 111-125. [CrossRef]

31. Jiang, H.; Zhang, Y. An investigation of service quality, customer satisfaction and loyalty in China's airline market. J. Air Transp. Manag. 2016, 57, 80-88. [CrossRef]

32. Anderson, E.W.; Fornell, C.; Lehmann, D.R. Customer satisfaction, market share, and profitability: Findings from Sweden. J. Mark. 1994, 58, 53-66. [CrossRef]

33. Homburg, C.; Koschate, N.; Hoyer, W.D. The role of cognition and affect in the formation of customer satisfaction: A dynamic perspective. J. Mark. Manag. 2006, 70, 21-31. [CrossRef]

34. Liu, Y.; Jang, S.S. Perceptions of Chinese restaurants in the US: what affects customer satisfaction and behavioral intentions? Int. J. Hosp. Manag. 2009, 28, 338-348. [CrossRef]

35. Yeh, T.M.; Chen, S.H.; Chen, T.F. The relationships among experiential marketing, service innovation, and customer satisfaction-A case study of tourism factories in Taiwan. Sustainability 2019, 11, 1041. [CrossRef]

36. Park, K.; Park, J.-W. The effects of the servicescape of airport transfer amenities on the behavioral intentions of transfer passengers: A case study on Incheon International Airport. J. Air Transp. Manag. 2018, 72, 68-76. [CrossRef]

37. Padgett, D.; Allen, D. Communicating experiences: A narrative approach to creating service brand image. J. Advert. 1997, 26, 49-62. [CrossRef] 
38. Abdullah, M.; Husain, N.; El-Nassir, A.D. Theory and development of National Customer Satisfac-Tion Index: The Malaysian Index of Customer Satisfaction. In Proceedings of the 6th TQM World Congress, St. Petersburg, Russia, 20-22 June 2001.

39. Johnson, M.D.; Gustafsson, A.; Andreassen, T.W.; Lervik, L.; Cha, J. The evolution and future of national customer satisfaction index models. J. Econ. Psychol. 2001, 22, 217-245. [CrossRef]

40. Hair, J.F.; Black, W.C.; Babin, B.J.; Anderson, R.E.; Tatham, R.L. Multivariate Data Analysis, 6th ed.; Pearson Prentice Hall: Upper Saddle River, NJ, USA, 2006.

41. Song, J.J. SPSS/AMOS Statistical Analysis Method; 21cbook: Paju, Korea, 2015; ISBN 978-898-468-618-2.

42. Oishi, S.; Schimmack, U.; Diener, E. Pleasures and subjective well-being. Eur. J. Personal. 2001, 15, $153-167$. [CrossRef]

43. Wirtz, J.; Mattila, A.S.; Tan, R.L. The moderating role of target-arousal on the impact of affect on satisfaction-an examination in the context of service experiences. J. Retail. 2000, 76, 347-365. [CrossRef]

(C) 2019 by the authors. Licensee MDPI, Basel, Switzerland. This article is an open access article distributed under the terms and conditions of the Creative Commons Attribution (CC BY) license (http://creativecommons.org/licenses/by/4.0/). 